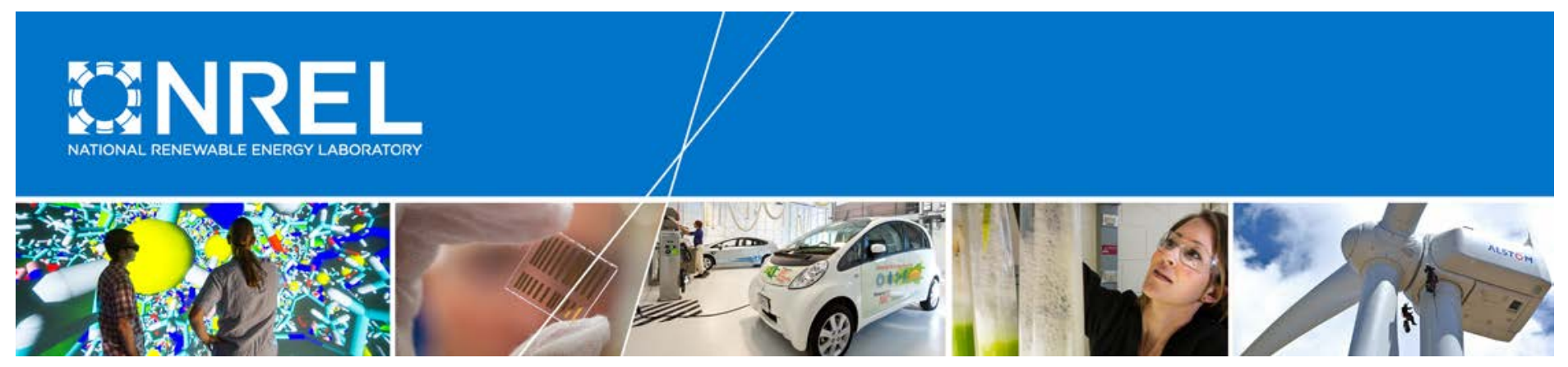

\title{
Marine Hydrokinetic Energy Site Identification and Ranking Methodology Part I: Wave Energy
}

Levi Kilcher and Robert Thresher

NREL is a national laboratory of the U.S. Department of Energy Office of Energy Efficiency \& Renewable Energy Operated by the Alliance for Sustainable Energy, LLC

This report is available at no cost from the National Renewable Energy Laboratory (NREL) at www.nrel.gov/publications.

Technical Report

NREL/TP-5000-66038

October 2016

Contract No. DE-AC36-08G028308 


\title{
Marine Hydrokinetic Energy Site Identification and Ranking Methodology Part I: Wave Energy
}

\author{
Levi Kilcher and Robert Thresher
}

Prepared under Task No. WA152001

NREL is a national laboratory of the U.S. Department of Energy Office of Energy Efficiency \& Renewable Energy Operated by the Alliance for Sustainable Energy, LLC

This report is available at no cost from the National Renewable Energy Laboratory (NREL) at www.nrel.gov/publications.

National Renewable Energy Laboratory 15013 Denver West Parkway Golden, CO 80401

303-275-3000 • www.nrel.gov
Technical Report

NREL/TP-5000-66038

October 2016

Contract No. DE-AC36-08GO28308 


\section{NOTICE}

This report was prepared as an account of work sponsored by an agency of the United States government. Neither the United States government nor any agency thereof, nor any of their employees, makes any warranty, express or implied, or assumes any legal liability or responsibility for the accuracy, completeness, or usefulness of any information, apparatus, product, or process disclosed, or represents that its use would not infringe privately owned rights. Reference herein to any specific commercial product, process, or service by trade name, trademark, manufacturer, or otherwise does not necessarily constitute or imply its endorsement, recommendation, or favoring by the United States government or any agency thereof. The views and opinions of authors expressed herein do not necessarily state or reflect those of the United States government or any agency thereof.

This report is available at no cost from the National Renewable Energy Laboratory (NREL) at www.nrel.gov/publications.

Available electronically at SciTech Connect http:/www.osti.gov/scitech

Available for a processing fee to U.S. Department of Energy and its contractors, in paper, from:

U.S. Department of Energy

Office of Scientific and Technical Information

P.O. Box 62

Oak Ridge, TN 37831-0062

OSTI http://www.osti.gov

Phone: 865.576.8401

Fax: 865.576.5728

Email: reports@osti.gov

Available for sale to the public, in paper, from:

U.S. Department of Commerce

National Technical Information Service

5301 Shawnee Road

Alexandria, VA 22312

NTIS http://www.ntis.gov

Phone: 800.553 .6847 or 703.605 .6000

Fax: 703.605.6900

Email: orders@ntis.gov 


\section{Acknowledgements}

This work would not be possible without the input of wave energy experts from industry, academia, and national laboratories. In particular, thanks to Reenst Lesemann and Pukha LeneeBluhm at Columbia Power Technologies; William Staby at Resolute Marine Energy; Tim Mundon and Rahul Shendure at OscillaPower; Charles Vinick at Ecosphere Technologies; Belinda Batten, Dan Hellin, and Brian Polagye at the Northwest National Marine Renewable Energy Center; Luis Vega, Richard Rocheleau, and Patrick Cross at the Hawaii Natural Energy Institute; Jason Busch and Matt Sanders at the Oregon Wave Energy Trust; Josh Ahmann at Parametrix; William Toman at California Polytechnic State University; Simon Geerlofs and Zhaoqing Yang at the Pacific Northwest National Laboratory; Vincent Neary and Annie Dallman at Sandia National Laboratory; Bryson Robertson at the University of Victoria; Heidi Tinnesand, Owen Roberts, Robi Robichaud, Jochem Weber, and Jason Cotrell at the National Renewable Energy Laboratory; and Joel Cline at the U.S. Department of Energy. Thanks especially to our sponsor, the U.S. Department of Energy, for funding this work under contract DE-AC36$08 \mathrm{GO} 28308$. 


\section{Abbreviations and Acronyms}

$\begin{array}{ll}\text { kWh } & \begin{array}{l}\text { kilowatt-hour } \\ \text { LCOE }\end{array} \\ \text { MCDA } & \text { Multi-Criteria Decision Analysis } \\ \text { MHK } & \text { marine hydrokinetic } \\ \text { MW } & \text { megawatt } \\ \text { NNMREC } & \text { Northwest National Marine Renewable Energy Center } \\ \text { REFSSA } & \text { Renewable Energy Facility Suitability Study Areas } \\ \text { REPA } & \text { Renewable Energy Permit Areas } \\ \text { U.S. DOE } & \text { U.S. Department of Energy } \\ \text { WEC } & \text { wave energy converter } \\ \text { WPD } & \text { wave power density }\end{array}$




\section{Executive Summary}

Marine hydrokinetic energy is a promising and growing piece of the renewable energy sector that offers high predictability and additional energy sources for a diversified energy economy. This report investigates the market opportunities for wave energy along the U.S. coastlines. It is part one of a two-part investigation into the United States' two largest marine hydrokinetic resources (wave and tidal).

Wave energy technology is still an emerging form of renewable energy for which large-scale grid-connected project costs are currently poorly defined. Ideally, device designers would like to know the resource conditions at economical project sites so they can optimize device designs. On the other hand, project developers need detailed device cost data to identify sites where projects are economical. That is, device design and siting are, to some extent, a coupled problem. This work describes a methodology for identifying likely deployment locations based on a set of criteria that wave energy experts in industry, academia, and national laboratories agree are likely to be important factors for all technology types.

The methodology is a multi-criteria decision analysis that uses six criteria to identify likely deployment locations:

- Resource density (wave power density)

- Market size

- Energy price (an estimate of avoided energy cost in the market)

- Distance to transmission

- Shipping cost

- Water depth.

Data for each criterion were collected from a range of sources, including the National Renewable Energy Laboratory's MHK Atlas (http://maps.nrel.gov/mhk_atlas) and the U.S. Energy Information Administration (http://eia.gov).

This work groups the data for the six criteria into locales that are defined as the smaller of either the local transmission grid or a state boundary. The former applies to U.S. islands (e.g., Hawaii, American Samoa) and rural villages (e.g., in Alaska); the latter applies to states in the contiguous United States. These data are then scored from 0 to 10 according to scoring functions that were developed with input from wave energy industry and academic ocean energy experts.

The scores are aggregated using a simple product method that includes a weighting factor for each criterion. This work presents two weighting scenarios: a long-term scenario that does not include energy price and a short-term scenario that does include energy price. The aggregated scores are then used to produce ranked lists of likely deployment locales. Results from the shortterm scenario indicate locations where wave energy is likely to be deployed first. The long-term scenario looks beyond the next few decades to a time when the industry has matured and the costs of wave energy approach parity with other technologies, and low-carbon electricity production becomes a higher priority. At that time, energy price is expected to be a less-critical project siting criteria. 
In both scenarios, Hawaii and the Pacific Northwest (Northern California, Oregon, and Washington) rank at the top of the lists. Hawaii ranks highest in the short-term scenario because it has high energy costs. In the long-term scenario, Oregon ranks highest because it has a large market and an energetic resource. Several East Coast states and Puerto Rico are also identified as potential wave energy deployment sites if technological innovations make it possible to efficiently generate electricity from the modest resource there. There are also several smallmarket sites in Alaska and U.S. Pacific Islands that rank particularly well in the short-term analysis due to their high energy prices. These locations may represent opportunities to demonstrate economical wave energy conversion as a stepping-stone to larger markets.

Several factors that will affect wave project costs and siting have not been considered hereincluding permitting constraints, conflicting use, seasonal resource variability, extreme event likelihood, and distance to ports - because consistent data are unavailable or technologyindependent scoring could not be identified. As the industry continues to mature and converge around a subset of device archetypes with well-defined costs, more precise investigations of project siting that include these factors will be possible. For now, these results provide a highlevel guide pointing to the regions where markets and resource will one day support commercial wave energy projects. 


\section{Table of Contents}

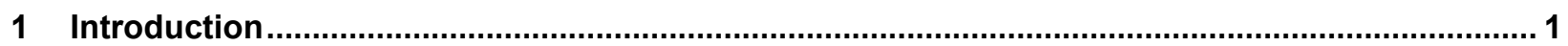

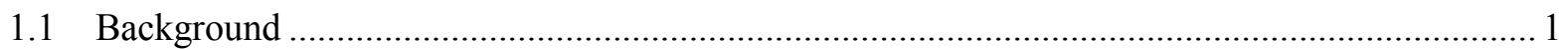

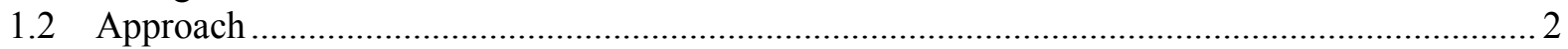

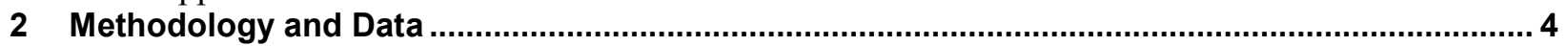

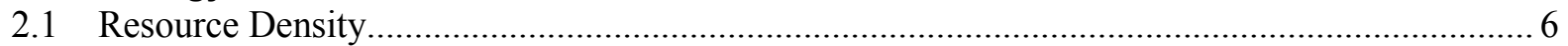

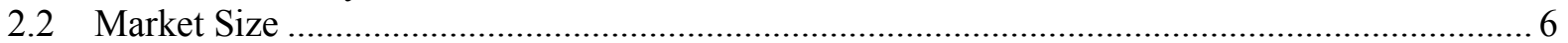

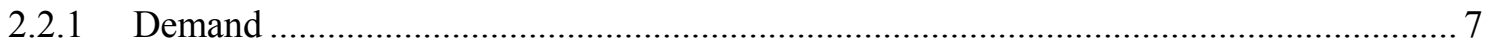

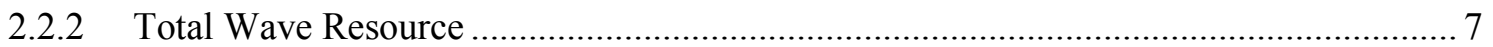

2.2.3 Market Size: Summary and Scoring................................................................... 8

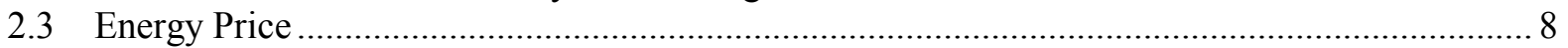

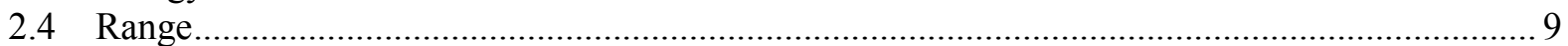

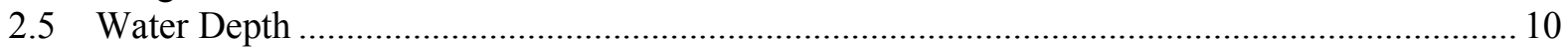

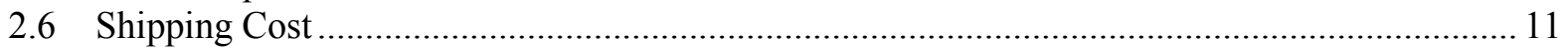

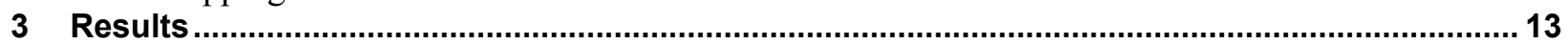

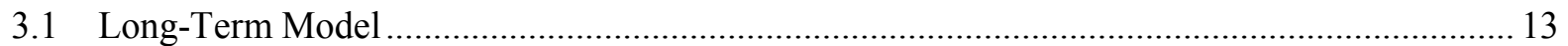

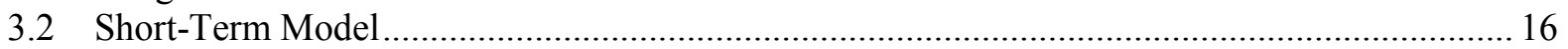

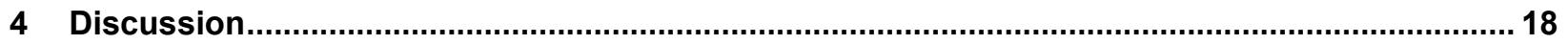

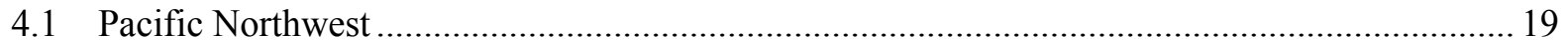

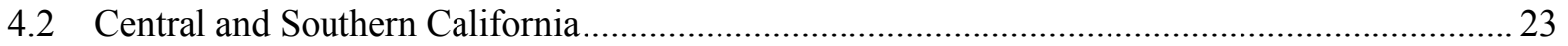

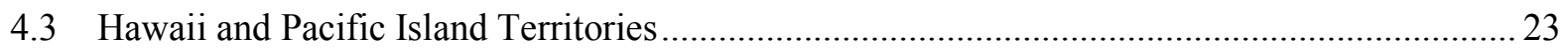

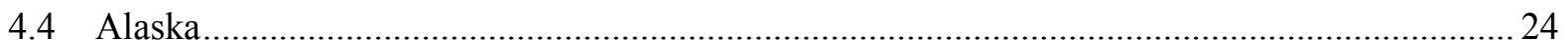

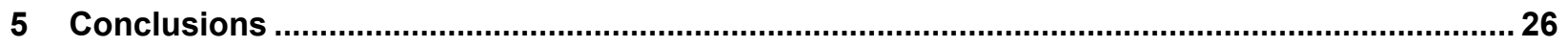

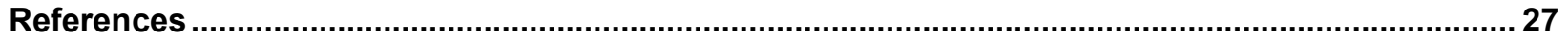




\section{List of Figures}

Figure 1. Wave resource map along the U.S. West Coast. ............................................................. 4 Figure 2. WPD scoring function. Locations with WPD less than $5 \mathrm{~kW} / \mathrm{m}$ are excluded from the analysis.

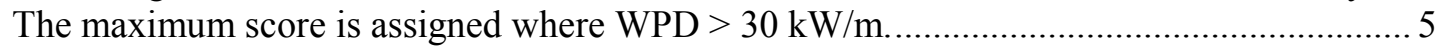

Figure 3. Market scores increase logarithmically from $300 \mathrm{~kW}$ to 4 gigawatts .................................... 8

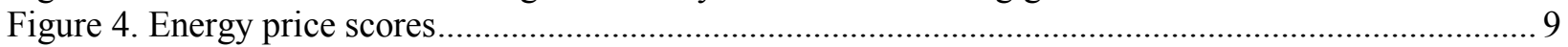

Figure 5. Scoring for distance between locale and resource (range) ...................................................... 10

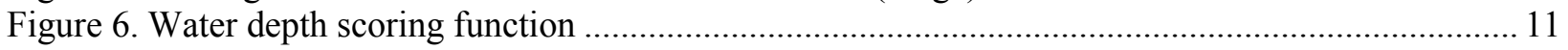

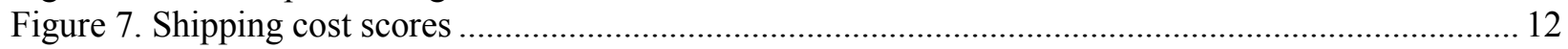

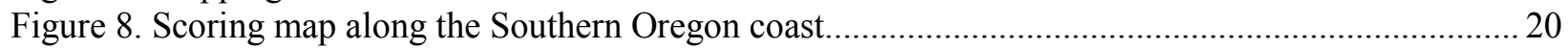

Figure 9. Map of scores at the Oregon - Washington border (the Columbia River)............................... 21

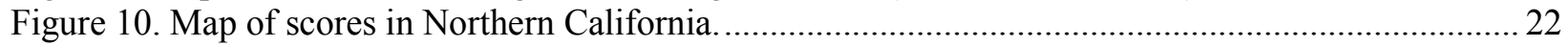

Figure 11. Southern California score map north of Point Conception................................................... 23

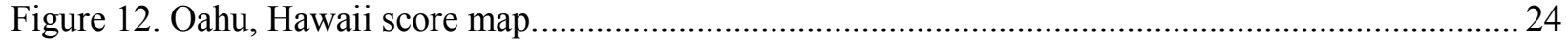

\section{List of Tables}

Table 1. Origin Port, Intermediate Port, and Parameters of the Shipping Cost Model for Each Region.... 11

Table 2. Ranking of Wave Energy Locales for the Long-Term Scoring Model....................................... 15

Table 3. Ranking of Wave Energy Locales for the Short-term Scoring Model........................................ 17

Table 4. Regional Summary Comparing Long-Term and Short-Term Analyses ................................... 18 


\section{Introduction}

In the modern era, with demand for electricity growing alongside the consequences posed by climate change, there is increasing need for a diverse portfolio of renewable energy sources. Established renewable energy technologies, such as wind and solar, have the potential to meet a large portion of the United States' energy demand, but as they've scaled up they've begun to encounter integration challenges that suggest a need for energy storage, as well as societal challenges such as competing land use and environmental impact concerns. Marine hydrokinetic (MHK) energy also has the potential to contribute significantly to the nation's energy needs, and-because it is located at sea and can be forecast with greater accuracy-may not have the same challenges. MHK energy can help to diversify the nation's energy portfolio and make the nation's future high-penetration renewable energy system more robust and reliable (Mai et al. 2012).

This report is the first in a two-part series on methods for identifying and ranking commercial MHK deployment locations. It is focused on wave energy site identification, and its companion report focuses on tidal energy site identification (Kilcher, Thresher, and Tinnesand 2016). Each of these reports utilizes publically available data for the U.S. coastline to provide a high-level assessment of the potential for MHK deployment in the United States.

\subsection{Background}

Wave energy is currently at a critical middle stage of the technology development process. A respected body of literature exists that describes the essential physics, classifies design types, and quantifies the resource potential (e.g., Bedard 2008; Hagerman and Scott 2011; Stopa et al. 2013). Several device designs have performed full- and mid-scale demonstrations that have generated electricity in the open ocean. In collaboration with regional organizations and universities, the U.S. Department of Energy (DOE) has established test centers where device designs can be tested in the most energetic locations with the full array of monitoring infrastructure that is needed for technology refinement (Batten and Polagye 2013, DeVisser et al. 2013). These test centers are critical for engineering the next generation of wave energy converters (WECs) and providing the data on cost, performance, and reliability necessary to gain acceptance from commercial investors. The next step in the technology development lifecycle is the deployment of commercial-scale arrays with capacities greater than 10 megawatts (MW). These larger arrays are expected to greatly reduce cost relative to demonstration projects and start the path toward cost parity with other sources of low-carbon generation through standardization, learning by doing, and increased scale.

Mirroring experience from the wind industry, where turbine designs have evolved for specific classes of wind speeds and turbulence conditions, DOE is supporting an effort to define a wave classification scheme that establishes standards for classifying critical wave site factors and conditions (International Electrotechnical Commission, 2015, 2011). For WECs, a critical design consideration is likely to be related to periodic storms that generate extreme sea states that have the potential to damage devices.

In order to engineer efficient, low-cost, robust devices that can gain commercial acceptance, the wave energy industry needs a more detailed understanding of the extreme conditions WEC devices will encounter. How many rogue waves will a wave device expect to see in a decade? 
How many extreme storms? How does the magnitude of the forces in these conditions compare to operational conditions? How much additional structural material is needed for devices to survive them? Do design changes for reliability reduce efficiency? How do these considerations contribute to the levelized cost of energy (LCOE) of wave technology?

DOE-funded national laboratories, including the National Renewable Energy Laboratory and Sandia National Laboratories, are developing simulation tools that help to answer these question by predicting performance and fatigue loading on wave devices in operational and extreme sea states (Ruehl et al. 2014); however, these tools require data that define the frequency and intensity of the events.

The wave classification scheme is designed to help WEC designers target a range of operational and extreme sea states that exist in specific locations. The classification scheme will establish a framework for more rapid commercialization of wave technology as all devices will not have to be designed for all conditions. In order for these efforts to be useful to U.S. technology developers, they require detailed knowledge of the typical ambient and extreme sea states that exist at likely commercial wave sites along the U.S. coastline. This report is intended to help identify those sites.

\subsection{Approach}

The objective of this work is to provide a consistent methodology for assessing wave energy opportunities along the entire U.S. coastline, including the East and West Coasts of the contiguous United States, Alaska, Hawaii, and all U.S. territories. Across this domain a wide range of factors contributes to project viability, including resource characteristics; market conditions; regulatory requirements; manufacturing capacity; and ports to support installation, operations, and maintenance. The diverse mix of these factors, their complex relationships, and the evolving state of wave energy technology add to the challenge of identifying the most suitable locations for wave technology deployment. Fortunately, there has already been significant work in this domain, especially in the regions where wave energy is considered to be a promising source of renewable energy (Geerlofs et al. 2011; Porter and Phillips 2016; "State of Oregon Territorial Sea Plan Part 5: Use of the Territorial Sea for the Development of Renewable Energy Facilities or Other Related Structures, Equipment, or Facilities," 2013; Stopa et al. 2013; Van Cleve et al. 2013; Vega 2010). The objective of this work is to provide a nationwide context for these studies and to bring U.S. locations not considered in those works into the discussion.

This analysis is organized into "locales," defined herein as sub-regions or sites that are either separated by legal boundaries (e.g., states) or are an isolated electrical grid (e.g., a Hawaiian Island or rural Alaskan village). This multi-faceted definition allows the ranking to include the diversity of MHK opportunities that exist in U.S. waters.

This work focuses on identifying and ranking locales independent of the technology or sitespecific details while still maintaining quantitative scoring criteria that produce meaningful rankings of MHK opportunities. It does not consider the permitting, alternate-use, or zoning considerations that may be important within a locale. The intent is to facilitate discussion on MHK opportunities with stakeholders and provide context for more detailed site-specific investigations by project developers and other organizations (e.g., Geerlofs et al. 2011; Stopa et 
al. 2013; Van Cleve et al. 2013; Vega 2010). Throughout this analysis, considerable effort is made to consider the range of locale types in a consistent, inclusive, and judicious manner.

The methodology is designed to rank sites based on high-level technical and economic factors that are important to current and future MHK technology and project development. Toward this end, this work presents two sets of results: 1) a long-term scenario, and 2) a short-term scenario. The short-term scenario includes the locale's energy price as a scoring criterion. This is important in the short term because wave energy is still relatively expensive compared to other types of generation, and therefore locales with higher energy prices will be more attractive to project developers. The long-term scenario does not include energy price. This is based on the expectation that wave energy costs will approach parity with other forms of generation over the next 10 to 20 years, and low-carbon electricity production becomes a higher priority. In that case, energy price will become a less-critical factor in project siting. The short- and long-term scenarios, therefore, provide complementary perspectives that identify market opportunities and suggest how those opportunities might evolve as the technology matures over the next few decades. 


\section{Methodology and Data}

This section provides a detailed description of the data and methods used in this report. All coastal U.S. states and U.S. territories are included in the analysis. At the smallest level, a locale is a rural isolated power grid with mean annual generation of at least 20 kilowatts $(\mathrm{kW})$ (e.g., rural Alaskan villages or Pacific Island communities). At the largest level, a locale is an entire state coastline (e.g., Oregon, Washington, Florida, Georgia, etc.). California's long coastline is divided into three locales: Southern California is south of 35.8N (Monterey-San Luis Obispo county border), Northern California is north of Pt. Arena (38.95N), and Central California spans the distance between them.

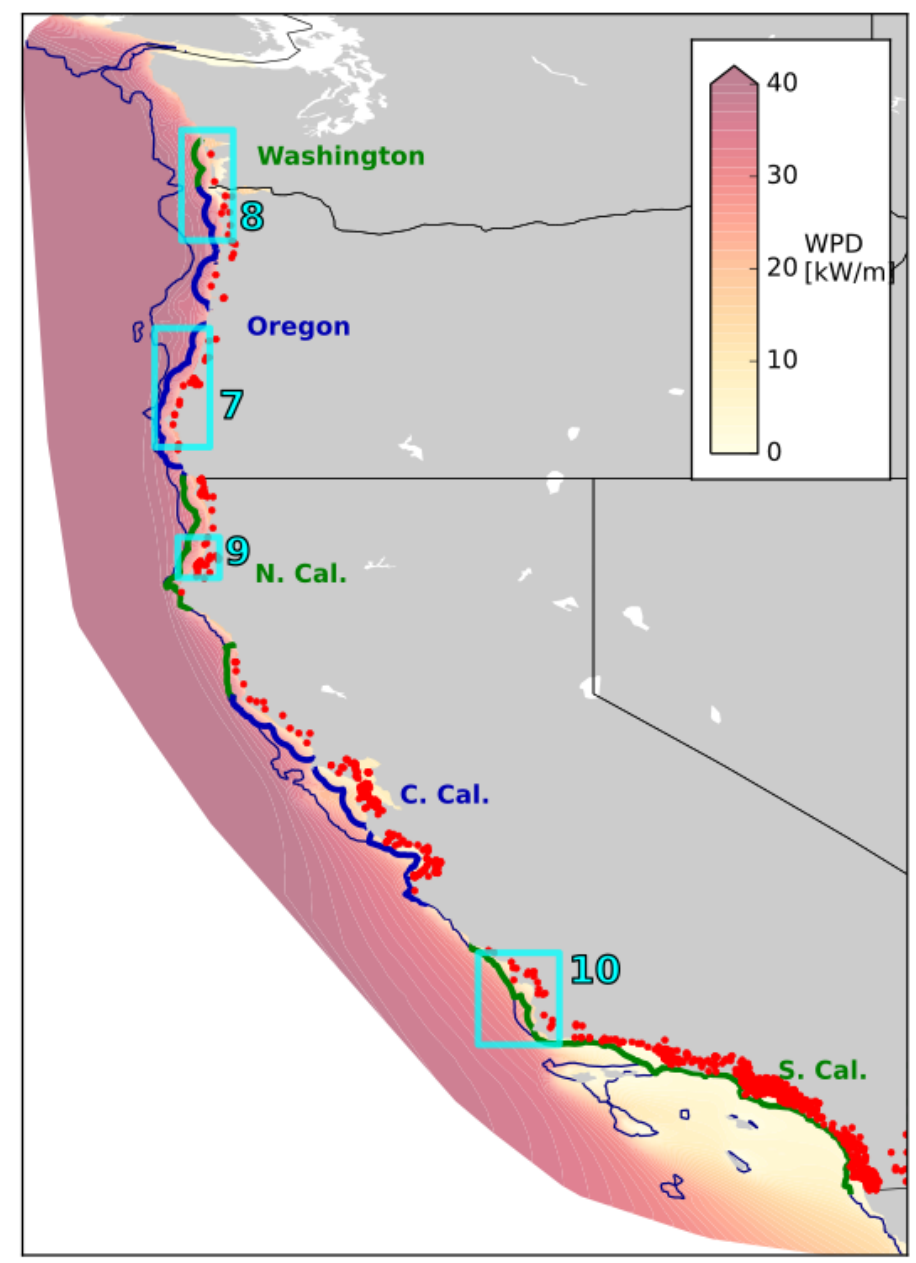

Figure 1. Wave resource map along the U.S. West Coast.

Wave power density is colored yellow (low) to mauve (high). Alternating blue and green contours for each locale indicate the boundary along which total wave energy is calculated. Red dots are coastal transmission/distribution substations. The thin blue line indicates the 200-m isobath. The numbered cyan boxes indicate locations of Figures 8-11.

We have chosen not to divide other states into smaller regions to avoid repeating the work of others who have performed more detailed state-specific wave site identification (e.g., Stopa et al. 2013; Van Cleve et al. 2013). This methodology produced a database of 100 locales distributed 
throughout the Pacific, along the U.S. east and west coastlines, within the Caribbean, and along the Alaskan coast.

Based on reviews of previous work, a search of publically available data, and a survey of industry experts, a set of key technology and market drivers was developed to estimate suitability for early deployment of wave energy technology. While other factors and criteria are important in selecting between particular locations, the key criteria for site assessment considered here are:

- Resource density

- Market size

- Energy price (short-term scenario only)

- Distance to point of interconnection

- Water depth

- Shipping cost.

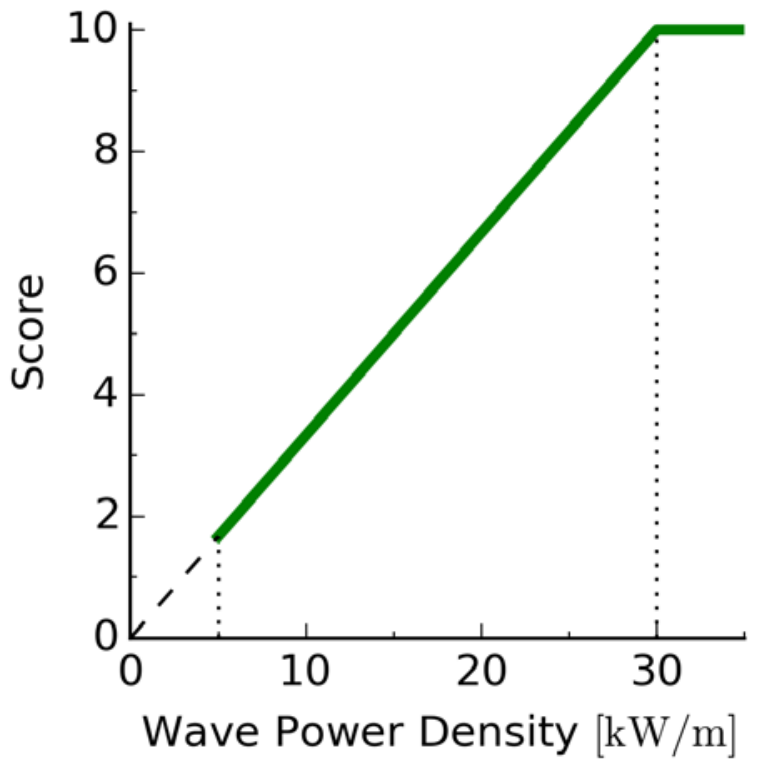

Figure 2. WPD scoring function. Locations with WPD less than $5 \mathrm{~kW} / \mathrm{m}$ are excluded from the analysis. The maximum score is assigned where WPD $>30 \mathrm{~kW} / \mathrm{m}$.

A Multi-Criteria Decision Analysis (MCDA) framework is used to score each of these criteria, create a composite score, and generate rankings of wave locales and tidal sites (Van Cleve et al. 2013; Wang et al. 2009).

Each of these criteria is scored on a scale from 0 to 10 and assigned a weight to set the relative importance of each criterion. The composite score is computed as a product of the weighted criterion as follows:

$$
S=\prod_{i} s_{i}^{w_{i}}
$$


Where, $s_{i}$ and $w_{i}$ are the scores and weights, respectively, for each criterion at each locale. ' $\Pi$ ' denotes a product of the weighted scores (i.e., $\left.\left(s_{1}{ }^{w_{1}}\right) \times\left(s_{2}{ }^{w_{2}}\right) \times \ldots\left(s_{5}{ }^{w_{5}}\right)\right)$. Note that the total composite score for a site, $S$, is between 0 and 10 if the weights are normalized such that, $\sum_{i} w_{i}=1$ (Wang et al. 2009). The data and software tools (Python package and scripts) used to score and rank sites in this analysis are available for download from the MHK Data Repository (submission id 154 ${ }^{\mathrm{i}}$ ).

These composite scores are used to rank sites in terms of their suitability for early MHK technology deployment. Detailed information on the data sources and scoring rationale for the long-term model for each of the criteria $s_{i}$ are provided below. Resource density and market size criteria are indicators of the technical and commercial viability of a potential project location. Higher resource density and larger markets are likely to be more attractive to project developers, and these criteria are therefore scored positively. The shipping cost, distance to resource, and water depth criteria are indicators for total project cost. Sites with larger costs are considered less attractive, and these criteria are therefore scored lower.

\subsection{Resource Density}

Wave power density (WPD) is the annual average incident wave power per segment of coastline, in units of $\mathrm{kW} / \mathrm{m}$ (International Electrotechnical Commission 2011). Several sources were used to obtain the WPD estimates for this study. The WPD estimates for most locales are from the DOE-funded 2011 Electric Power Research Institute study "Mapping and Assessment of the United States Ocean Wave Energy Resource" (Hagerman and Scott 2011). These WPD estimates are based on a 51-month Wave Watch III hind-cast. Estimates of WPD at the Pacific Island territories that were not included in the Hagerman and Scott report were estimated from the U.S. Army Corps' Wave Information Studies database, which also utilized a Wave Watch III hindcast for more widely dispersed locations (Hanson et al. 2009).

WPD is scored linearly from 0 to $30 \mathrm{~kW} / \mathrm{m}$ and locals with resources less than $5 \mathrm{~kW} / \mathrm{m}$ were excluded from the analysis. The upper value, $30 \mathrm{~kW} / \mathrm{m}$, is selected because it is an industry standard value for a "fully energetic site" (Van Cleve et al. 2013). The threshold value of 5 $\mathrm{kW} / \mathrm{m}$ was selected based on prior work in this area and from industry feedback, which suggests that $10-15 \mathrm{~kW} / \mathrm{m}$ is an appropriate minimum threshold for wave energy siting in the next few decades. The value of $5 \mathrm{~kW} / \mathrm{m}$ is used to extend the analysis to longer timescales when lower power sites might become economically viable and to consider locations that would be excluded from other studies but may have otherwise favorable siting considerations. This resource scoring function is agnostic to technology-specific details, emphasizes the value of larger resource, and excludes sites with a very low resource.

\subsection{Market Size}

Wave energy market size is the maximum amount of wave energy that can be sold in a given locale. This is limited by two factors: 1) the maximum potential demand for wave energy within the locale, and 2) the total wave energy available near the locale. Therefore, market size is calculated as the smaller of the two quantities: demand and total wave resource.

${ }^{\mathrm{i}}$ http://mhkdr.openei.org/submissions/154 


\subsubsection{Demand}

Locale-specific estimates of maximum potential demand for wave energy do not currently exist and depend on a range of highly uncertain economic and political factors. Instead, the current load of a locale's electric grid is used as a proxy for potential demand for wave energy. This is based on the assumption that locales with larger electric grids will be capable of supporting larger wave projects, which are attractive for economy of scale benefits and could lead to reduced LCOE.

This approach is reasonable because the uncertainty associated with it is small compared to the range of loads considered here. For example, a $600-\mathrm{kW}$ rural Alaskan village is unlikely to suddenly create infrastructure that will generate demand for $50 \mathrm{MW}$ of wave generation capacity. Furthermore, the ranking is based on the relative attractiveness of U.S. MHK sites, and load is a reasonable proxy for relative demand of any economical energy source. Load data were compiled from the following sources:

- Rural Alaskan communities: Alaska Energy Authority's Power Cost Equalization (PCE) report (2013 PCE Report, 2014)

- Hawaiian Islands: Hawaiian State Energy Office Facts and Figures (Hawaiian State Energy Office 2014)

- Pacific Islands Territories: Various NREL technical reports and the Marshall Energy company website (Baring-Gould, Hunsberger, Visser, and Voss 2011; Baring-Gould, Conrad, Haase, Hotchkiss, McNutt 2011; Busche, Conrad, Funk, Kandt, McNutt 2011; Marshalls Energy Company 2013)

- For all other U.S. states, load data are from the U.S. Energy Information Administration (Retail Sales of Electricity 2013)

- For each California locale (Northern, Central, Southern), the Energy Information Administration total was portioned by population.

\subsubsection{Total Wave Resource}

The total wave power was estimated from the WPD data (Hagerman and Scott 2011). Because this dataset does not yet include wave energy directionality, we assume omni-directional wave power propagates in the mean wave flux direction. We then compute the total theoretical energy as the flux of this vector crossing a contour around the site, island, or coastline (i.e., sum of dotproducts around the locale). This contour is taken as the nearer of $20 \mathrm{~km}$ from transmission substations on the locale's grid or the 200-m depth contour. We use this "vector dot-product method" - as opposed to summing wave energy magnitude - because it provides a conservative estimate of total available power that is insensitive to contour details (wiggles and folds). The theoretical estimate is then multiplied by a "knockdown factor" of 0.5 to obtain an estimate of the total practical resource. This factor is meant to account for a) regions that will be excluded from development and $b$ ) wave farm efficiency. While the value of the knockdown factor is likely to be high, its primary purpose is to equalize the total resource estimates with demand so that the two variables can be compared and used as an estimate of relative market size for comparing locales. Since the above estimate of demand is also biased high, the value of 0.5 for the knockdown factor is reasonable. 


\subsubsection{Market Size: Summary and Scoring}

In summary, we compute the total practical resource for each locale then compare this to the potential demand (load) for wave energy at that locale. The smaller of the two values is taken as an estimate of market size.

In general, this work is designed to favor locales with large markets because economies of scale are highly attractive to MHK project developers. On the other hand, the scoring is intended to include small markets that have highly favorable site conditions, which may be valuable as early commercial projects. To account for these factors and uncertainties, we score market size logarithmically from $300 \mathrm{~kW}$ to 5 gigawatts (Figure 3). This function captures the logarithmic distribution of the markets considered in this analysis and produces a scoring that is more sensitive for small markets (e.g., $<10 \mathrm{MW}$ ) and less sensitive for the large markets that are assumed to be capable of generating demand for wave energy deployments. The $300-\mathrm{kW}$ threshold is assumed herein to be the minimum market size for wave energy projects to be economical. This is based on the idea that several project development activities - such as permitting, operations, installation, and grid integration-will have fixed minimum costs that cannot be recovered by very small wave energy projects. While the $300-\mathrm{kW}$ value is rather arbitrary, it is chosen as a balance between a) screening out very small markets that are unlikely to support wave project development of existing technologies and b) including small, highenergy-price markets that may serve as early adopters of these technologies.

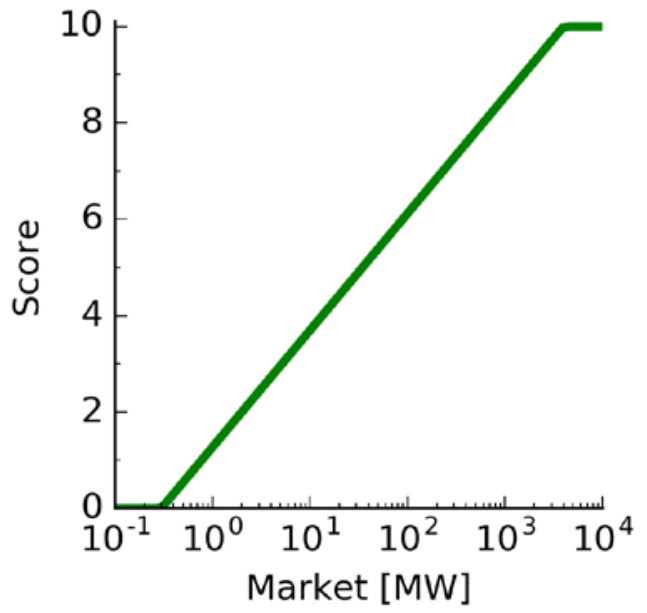

Figure 3. Market scores increase logarithmically from $300 \mathrm{~kW}$ to 4 gigawatts

\subsection{Energy Price}

Energy price is an estimate of the price a utility could pay a power producer for electricity in today's market. This is frequently conceptualized as the "avoided cost" of energy. Given existing infrastructure, avoided cost is the value to the utility of generating one additional unit of electricity. It is therefore the maximum a utility could pay a power provider for electricity without subsidizing that electricity or raising rates. While this approach does not account for market growth or mechanisms that raise the value or increase demand for wave energy specifically (e.g., subsidies or renewable portfolio standards), it provides a reasonable estimate of the value of wave energy in the existing marketplace in the near future. 
For small island nations and rural communities in Alaska, this work uses fuel cost per unit of energy (USD/kilowatt-hour, or $\mathrm{kWh}$ ) as an estimate of the energy price. This is justified because fuel costs account for the vast majority of avoidable costs in these markets. In larger markets (contiguous United States and Hawaii), the industrial rate is used as a proxy for energy price. This is justified because industrial (i.e., bulk) rates are typically only minimally higher than avoided costs.

The markets considered here have a wide range of energy prices: from a few cents to more than $\$ 0.50$ per $\mathrm{kWh}$. Energy price is scored linearly from a score of 0 at $\$ 0.00$ up to 10 at a cost of $\$ 0.50 / \mathrm{kWh}$ (Figure 4). This linear increase captures the increasing attractiveness of a project as the price of electricity increases in that locale. The upper bound is set to $\$ 0.50 / \mathrm{kWh}$ because costs above that are probably unsustainable (other renewables could enter the market at that cost, or the price is artificially high).

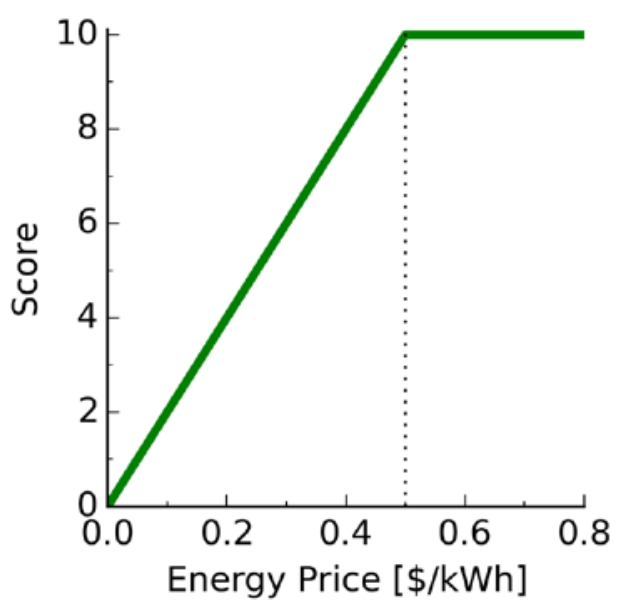

Figure 4. Energy price scores

\subsection{Range}

Range is the distance from each resource point to the nearest grid feature on the locale's power grid (in kilometers $[\mathrm{km}]$ ). The range scores are chosen according to the following criteria: 1 ) Locales with a range less than the precision of the analysis (i.e., the grid spacing of the wave resource data: $5 \mathrm{~km}$ ) are assigned a maximum score. 2) From 5 to $20 \mathrm{~km}$, scores decrease linearly to emphasize the importance of transmission costs to project viability. Resource estimates farther than $20 \mathrm{~km}$ from a locale are considered to have prohibitively high transmission costs and are therefore assigned a score of 0 . 


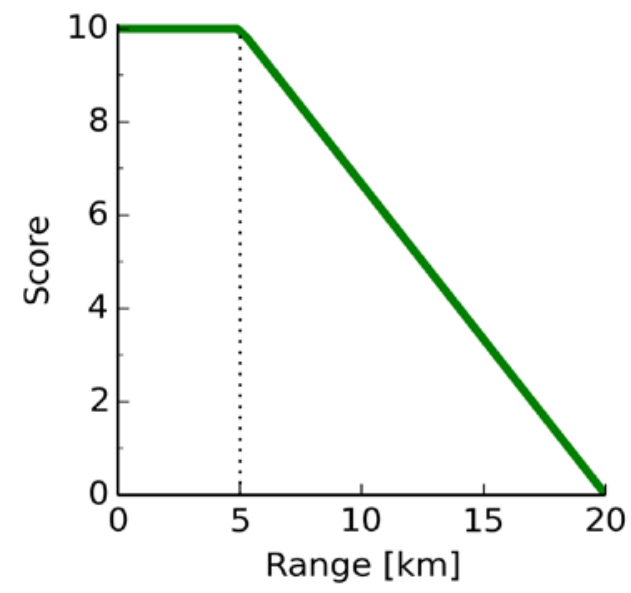

Figure 5. Scoring for distance between locale and resource (range)

\subsection{Water Depth}

Water depth (bathymetry) data were taken from the publically available National Oceanic and Atmospheric Administration Geophysical Data Center, which is a compilation of the U.S.

National Ocean Service Hydrographic Database, the U.S. Geological Survey, the Monterey Bay Aquarium Research Institute, the U.S. Army Corps of Engineers, and other academic institutions.

Water-depth scores are taken from Van Cleve et al. (2013) and organized into a single technology agnostic scoring function, based on the following:

- Deepwater devices are best suited to depths up to $125 \mathrm{~m}$, with decreasing suitability beyond this.

- Nearshore devices are best suited for 10- to 20-m water depth.

From this we define the cut-off depth at $5 \mathrm{~m}$ and a linearly decreasing scoring function from 125 to $400 \mathrm{~m}$ (Figure 6). Between 5 and $125 \mathrm{~m}$, we assume there could be some wave technology that is well suited for that water depth, and so we assign maximum scores for these depths. This catch-all approach seems reasonable until wave energy conversion technology converges on an economical device archetype with more specific operating specifications. 


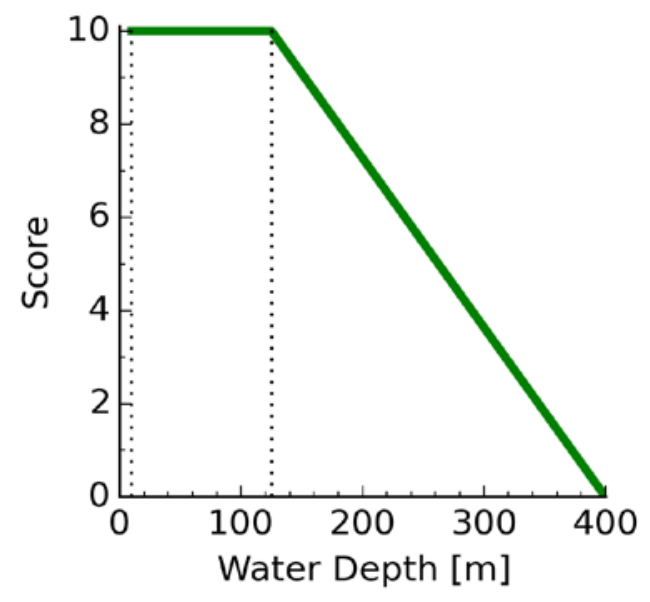

Figure 6. Water depth scoring function

\subsection{Shipping Cost}

Shipping costs are estimated in units of U.S. dollars per metric-tonne using a simple shippingdistance model (USD/ton). The model is designed to account for the challenge and added cost of developing, manufacturing, or transporting, installing, operating, and maintaining a wave farm at locations that are distant from the contiguous United States where the technology is expected to originate. The model calculates costs from one of three mainland-U.S. deep-water ports: Seattle, WA; Los Angeles, CA; and Miami, FL. These ports were selected as representative hubs that serve as the origin port for goods and services that would be delivered to WEC sites during installation, operations, and decommissioning. Consideration for port details such as heavy-lift capacity and water depth are important for more detailed studies of site suitability but are beyond the scope of this work.

The cost model used is

$$
C_{s}=r \cdot D_{i}+C_{i}
$$

Where $C_{s}$ is the total shipping cost to the site, $C_{i}$ is the cost to ship to the regional 'intermediate port', $r$ is the 'regional shipping rate' in USD per tonne per mile, and $D_{i}$ is the distance between the intermediate port and the site in miles. Values for $r$ and $C_{i}$ (Table 1) for each region were estimated from publically available shipping cost data (SeaRates.com 2015). Coastal states within the contiguous 48 states are assumed to have low shipping costs.

Table 1. Origin Port, Intermediate Port, and Parameters of the Shipping Cost Model for Each Region

\begin{tabular}{|l|l|l|l|l|}
\hline Region & Origin Port & Intermediate Port & $\boldsymbol{r}$ (USD/ton/mile) & $\boldsymbol{C}_{\boldsymbol{i}}$ (USD/ton) \\
\hline Caribbean & Miami, FL & San Juan, PR & 0.08 & 38 \\
\hline Pacific & $\begin{array}{l}\text { Los Angeles, } \\
\text { CA }\end{array}$ & Honolulu, HI & 0.08 & 88 \\
\hline Alaska Southeast & Seattle, WA & -- & 0.10 & 0 \\
\hline Alaska & Seattle, WA & Anchorage, AK & 0.12 & 84 \\
\hline Alaska Bering Sea & Seattle, WA & Dutch Harbor, AK & 0.15 & 180 \\
\hline
\end{tabular}


The shipping costs are given a maximum score for shipping costs below $60 \mathrm{USD}$ /ton (Figure 7). This value serves as an estimate of the intra-contiguous U.S. shipping costs that all projects will bear. That is, it accounts for the uncertainty in the intra-contiguous U.S. shipping costs that are considered low enough to receive high scores. Above $60 \mathrm{USD} /$ ton, the scores decrease linearly to account for the added costs associated with developing and operating these projects at remote locations. Shipping costs above $\$ 500$ USD/ton are considered prohibitively expensive and are assigned a score of zero.

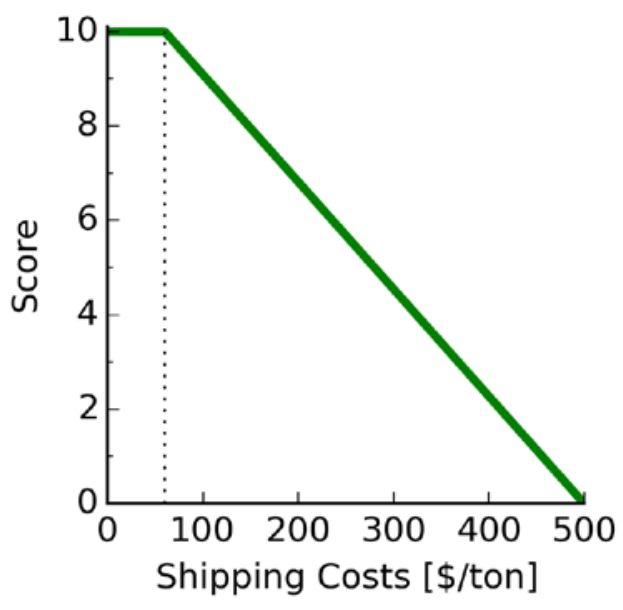

Figure 7. Shipping cost scores 


\section{Results}

Through this work, 34 wave locales were found to have the minimum load $(300 \mathrm{~kW})$ and resource $(5 \mathrm{~kW} / \mathrm{m})$ characteristics to be included in the analysis. This section provides the results of two analyses based on a) a long-term model that neglects energy price and b) a short-term model that includes it. Neither of these models provides a definitive ranking of the most viable wave energy locations. A definitive ranking would require technology-specific cost data for all potential technology types. Given the emerging state of the wave energy sector, cost data are patchy, held as private intellectual property, or do not yet exist. Given this, the results below should be seen as guideposts to the regions where wave energy technology is likely to be commercially viable.

\subsection{Long-Term Model}

The long-term model uses a weight of 0 for the energy price criteria and uses equal weight (1/5) for each of the other five scoring criteria. This model is meant to identify the locales where wave energy technology is most viable in terms of market-size and resource-details. Energy price is excluded from the long-term model for two reasons. First, as the technology matures in the next several decades the costs of wave energy will approach parity with other renewables. In that case, the importance of energy price in determining site attractiveness decreases relative to market size and resource details. Second, energy price is likely to fluctuate considerably over the next several decades. In particular, as markets evolve, renewable portfolio standards approach deadlines, and other incentives emerge, the energy price landscape for wave energy may change dramatically.

It is clear from Table 2 that WPD and Market are the dominant factors that determine rankings for the long-term model. This is expected because these criteria have the largest variability. The Pacific Northwest (Oregon, Northern California, and Washington) is clearly the region best suited for wave energy development in the United States over the long term (Table 2). These locales all have a highly energetic wave resource within $20 \mathrm{~km}$ of existing transmission infrastructure. These locales each have at least one major trade port, which suggests that shipping, manufacturing, and operations costs will be low compared to locations that are distant from major U.S. shipping ports. Oregon and Northern California have significant coastal transmission infrastructure that could be modified to deliver several hundred megawatts of power to consumers. In both of these locales, the total resource exceeds the local load (i.e., they are "load limited"), indicating that developing even a fraction of the total resource would contribute significantly to the locale's energy needs. Washington has a large total wave resource, but the state's outer-coast infrastructure is limited to a few towns along the southern third of that coastline (Figure 1). Sizable transmission projects or storage-transport technology would be required for wave energy to contribute significantly to the state's energy needs. Washington's wave energy potential is therefore classified as "transmission limited."

Both Central and Southern California have very large total wave resources and massive infrastructure capable of delivering wave energy to consumers. These locales rank below the Pacific Northwest due to lower WPD. Still, the WPD north of Point Conception is a highly energetic and potentially valuable renewable energy resource. The size of the market and the presence of coastal transmission infrastructure make these locales highly attractive. A detailed 
feasibility study for a potential wave energy test site in California is in preparation and expected to be published soon.

The next four locales are the Hawaiian Islands, with coasts exposed to the North Pacific Ocean. Oahu ranks highest among these because it has an energetic resource and the largest load of all the islands. The island of Kauai also has an energetic resource but a lower market size. The islands of Maui and Hawaii rank lower because sites with acceptable water depths have lower WPD. The more refined analyses of Stopa et al. (2013) and Vega (2010) provide more details of site identification for these islands.

The next three sites - Puerto Rico, North Carolina, and Majuro (Marshall Islands) — are case studies for the remainder of the sites on the list. Puerto Rico and North Carolina have a large demand for electricity, but their resource is relatively small. Majuro has a moderate resource, a small load, and very high shipping costs. East Coast states generally rank low, primarily because the annual-average WPD is small. It is difficult to say whether locations with WPD less than 10 $\mathrm{kW} / \mathrm{m}$ will produce economical power. Several Alaskan communities (most notably, Yakutat) and Pacific Island territories rank low because their markets are small and shipping costs high. Guam and Saipan stand out as locations that rank low because of their shipping costs alone. They have a moderate WPD of 14 and $17 \mathrm{~kW} / \mathrm{m}$ and a sizable load of 34 and $210 \mathrm{MW}$, respectively. 
Table 2. Ranking of Wave Energy Locales for the Long-Term Scoring Model.

Darker greens indicate higher scores in each category. "L," " $R$," and " $T$ " in the market column indicate whether the locale is primarily load-, resource-, or transmission-limited. The scoring criteria Resource,

Market, Range, Shipping, and Depth are each weighted equally (1/5) to compute the total score.

\begin{tabular}{|c|c|c|c|c|c|c|c|c|c|}
\hline & & Region & $\begin{array}{l}\text { Resource } \\
{[\mathrm{kW} / \mathrm{m}]}\end{array}$ & $\begin{array}{l}\text { Market } \\
{[\mathrm{MW}]}\end{array}$ & & $\begin{array}{l}\text { Range } \\
{[\mathrm{km}]}\end{array}$ & \begin{tabular}{|l} 
Shipping \\
[\$/ton]
\end{tabular} & $\begin{array}{l}\text { Depth } \\
{[\mathrm{m}]}\end{array}$ & Score \\
\hline 1 & Oregon & West Coast & 31 & 5,400 & $\mathrm{~L}$ & 4.2 & 0 & 78 & 10.0 \\
\hline 2 & N. California & West Coast & 31 & 1,400 & $\mathrm{~L}$ & 5.4 & 0 & 99 & 9.7 \\
\hline 3 & Washington & West Coast & 30 & 620 & $\mathrm{~T}$ & 4.7 & 0 & 87 & 9.5 \\
\hline 4 & C. California & West Coast & 25 & 2,500 & $\mathrm{R}$ & 6.0 & 0 & 92 & 9.4 \\
\hline 5 & S. California & West Coast & 22 & 1,300 & $\mathrm{R}$ & 6.0 & 0 & 51 & 9.0 \\
\hline 6 & Oahu & Pacific & 23 & 350 & $\mathrm{R}$ & 6.7 & 89 & 96 & 8.6 \\
\hline 7 & Maui & Pacific & 20 & 140 & $\mathrm{~L}$ & 8.5 & 96 & 134 & 7.8 \\
\hline 8 & Kauai & Pacific & 23 & 52 & $\mathrm{~L}$ & 8.2 & 97 & 150 & 7.7 \\
\hline 9 & Hawaii & Pacific & 13 & 140 & $\mathrm{~L}$ & 5.2 & 103 & 127| & 7.5 \\
\hline 10 & Puerto Rico & Caribbean & 7 & 340 & $\mathrm{R}$ & 8.3 & 40 & 128 & 6.7 \\
\hline 11 & North Carolina & East Coast & 5 & 940 & $\mathrm{R}$ & 7.6 & 0 & 19 & 6.5 \\
\hline 12 & Majuro & Pacific & 18 & 7.0 & $\mathrm{~L}$ & 5.0 & 271 & 100 & 6.4 \\
\hline 13 & New York & East Coast & 5 & 460 & $R$ & 8.8 & 0 & 29 & 6.3 \\
\hline 14 & Massachusetts & East Coast & 5 & 460 & $\mathrm{R}$ & 9.5 & 0 & 18 & 6.3 \\
\hline 15 & Tutuila & Pacific & 14 & 18 & $\mathrm{~L}$ & 3.0 & 297 & 60 & 6.2 \\
\hline 16 & Guam & Pacific & 14 & 210 & $\mathrm{~L}$ & 4.0 & 392 & 100 & 6.0 \\
\hline 17 & Saipan & Pacific & 17 & 34 & $\mathrm{~L}$ & 5.0 & 384 & 100 & 5.9 \\
\hline 18 & \begin{tabular}{|l|} 
Rhode Island \\
\end{tabular} & East Coast & 5 & 190 & $\mathrm{R}$ & 10.4 & 0 & 30 & 5.9 \\
\hline 19 & Molokai & Pacific & 9 & 3.9 & $\mathrm{~L}$ & 5.7 & 93 & 76 & 5.9 \\
\hline 20 & Lanai & Pacific & 9 & 3.1 & $\mathrm{~L}$ & 5.7 & 94 & 76 & 5.8 \\
\hline 21 & Kodiak & Alaska & 9 & 16 & $\mathrm{~L}$ & 13.3 & 114 & 37 & 5.5 \\
\hline 22 & Maine & East Coast & 5 & 760 & $\mathrm{R}$ & 15.8 & 0 & 138 & 5.2 \\
\hline 23 & Yakutat & Alaska & 22 & 0.63 & $\mathrm{~L}$ & 9.4 & 108 & 98 & 5.1 \\
\hline 24 & USVI & Caribbean & 6 & 42 & $\mathrm{R}$ & 15.4 & 45 & 42 & 5.0 \\
\hline 25 & Ebeye & Pacific & 12 & 1.8 & $\mathrm{~L}$ & 8.0 & 284 & 100 & 4.9 \\
\hline 26 & Tinian & Pacific & 9 & 5.0 & $\mathrm{~L}$ & 5.0 & 385 & 100 & 4.7 \\
\hline 27 & Unalaska & Alaska & 8 & 5.2 & $\mathrm{~L}$ & 14.3 & 179 & 129 & 4.6 \\
\hline 28 & Sitka & Alaska & 13 & 13 & $\mathrm{~L}$ & 18.2 & 85 & 44 & 4.5 \\
\hline 29 & Rota & Pacific & 14 & 1.8 & $\mathrm{~L}$ & 7.0 & 389 & 100 & 4.5 \\
\hline 30 & Saint Paul & Alaska & 10 & 0.43 & $\mathrm{~L}$ & 4.9 & 219 & 18 & 3.9 \\
\hline 31 & Naval Base Guam & Pacific & 14 & 27 & $\mathrm{~L}$ & 18.0 & 393 & 100 & 3.7 \\
\hline
\end{tabular}




\subsection{Short-Term Model}

The short-term model adds the energy price scoring criteria. In this model, all six criteria described in the methodology section are weighted equally (1/6). Wave energy technology is relatively new, and estimates of its costs are higher compared to other renewable and conventional generation sources. The short-term model includes energy price as a scoring criteria to identify locations where wave energy can compete with existing generation sources in the near future.

At the present time, the LCOE of wave and tidal technologies is high compared to conventional generation sources and mature renewables such as wind and solar. Throughout the marine energy industry and DOE, there is broad agreement that accelerated deployment is critical to generating the knowledge that is needed to engineer a new generation of low-cost technologies. This strategy follows from experience in the early years of the wind energy industry (1970s and '80s), in which aggressive deployment in locations with favorable market conditions led to technological breakthroughs that lowered LCOE and thereby expanded the marketability of wind energy. To inform a similar trajectory for wave energy, the short-term model identifies U.S. markets that may be able to support commercial deployment of existing technologies over the next 10 to 20 years.

Including energy price as a scoring criterion produces changes in locale ranking (Table 3 ). In this model, because energy price scores tend to be inverse to load scores, large markets often move down relative to smaller high-price markets. The Hawaiian Islands of Oahu and Kauai have replaced Oregon at the top of the list. Northern California - with its moderate energy priceremains near the top of the list (moving from 2 to 3), while Oregon and Washington-both with very low energy prices - now fall below the four most populated Hawaiian Islands and the California locales. The Pacific Island of Majuro, with an energy price of $\$ 0.36 / \mathrm{kWh}$, has moved up relative to Puerto Rico, North Carolina, and Washington.

Similar to the swap of the Hawaiian Islands with Oregon, the small Pacific Island markets of Tutuila, Guam, and Saipan, as well as Yakutat, Alaska - all of which have high energy pricesmove up relative to the East Coast states. These locales are particularly attractive early-market sites because the technology development cycle of early devices may not require large markets. Tutuila and Saipan, in particular, offer a mix of modest resource, market size, and energy price that may be ideal for technology development. Yakutat has a somewhat more energetic resource and a higher energy price, but the market is rather small. Massachusetts and Rhode Island are the top East Coast locales in this short-term model because they have relatively high energy costs compared to North Carolina and New York. Still, it is unclear whether economical wave energy can be produced from the modest resource that exists along the eastern coast. 
Table 3. Ranking of Wave Energy Locales for the Short-term Scoring Model.

Darker greens indicate higher scores in each category. The far right column indicates the change in rank (relative to the long-term model) of each locale. Negative rank change (red) indicates the locale moved down relative to the long-term model, positive rank change (blue) indicates the locale moved up. Each scoring criteria is weighted equally (1/6) to compute the total score from which locales are ranked.

\begin{tabular}{|c|c|c|c|c|c|c|c|c|c|c|c|}
\hline & & Region & $\begin{array}{l}\text { Resource } \\
{[\mathrm{kW} / \mathrm{m}]}\end{array}$ & $\mid \begin{array}{l}\text { Market } \\
{[\mathrm{MW}]}\end{array}$ & & $\begin{array}{l}\text { Energy } \\
\text { Cost } \\
{[\$ / k W h]}\end{array}$ & \begin{tabular}{|l} 
Range \\
{$[\mathrm{km}]$}
\end{tabular} & $\begin{array}{l}\text { Shipping } \\
\text { [\$/ton] }\end{array}$ & $\begin{array}{l}\text { Depth } \\
{[\mathrm{m}]}\end{array}$ & Score & $\begin{array}{c}\text { Rank } \\
\text { Change }\end{array}$ \\
\hline 1 & Oahu & Pacific & 23 & 350 & $\mathrm{R}$ & 0.28 & 6.7 & 89 & 96 & 8.0 & 5 \\
\hline 2 & Kauai & Pacific & 23 & 52 & $\mathrm{~L}$ & 0.36 & 8.2 & 97 & 150 & 7.6 & 6 \\
\hline 3 & N. California & West Coast & 31 & 1,400 & $\mathrm{~L}$ & 0.11 & 5.4 & 0 & 99 & 7.6 & -1 \\
\hline 4 & Maui & Pacific & 20 & 140 & $\mathrm{~L}$ & 0.31 & 8.5 & 96 & 134 & 7.5 & 3 \\
\hline 5 & C. California & West Coast & 25 & 2,500 & \begin{tabular}{l|l}
$\mathrm{R}$ \\
\end{tabular} & 0.11 & 6.0 & 0 & 92 & 7.4 & -1 \\
\hline 6 & Hawaii & Pacific & 13 & 140 & $\mathrm{~L}$ & 0.34 & 5.2 & 103 & 127 & 7.4 & 3 \\
\hline 7 & S. California & West Coast & 22 & 1,300 & \begin{tabular}{l|l}
$\mathrm{R}$ & \\
\end{tabular} & 0.11 & 6.0 & 0 & 51 & 7.1 & -2 \\
\hline 8 & Oregon & West Coast & 31 & 5,400 & L & 0.06 & 4.2 & 0 & 78 & 7.0 & -7 \\
\hline 9 & Majuro & Pacific & 18 & 7.0 & $\mathrm{~L}$ & 0.36 & 5.0 & 271 & 100 & 6.5 & 3 \\
\hline 10 & Washington & West Coast & 30 & 620 & $\mathrm{~T}$ & 0.04 & 4.7 & 0 & 87 & 6.4 & -7 \\
\hline 11 & Puerto Rico & Caribbean & 7 & 340 & $\mathrm{R}$ & 0.22 & 8.3 & 40 & 128 & 6.2 & -1 \\
\hline 12 & Molokai & Pacific & 9 & 3.9 & $\mathrm{~L}$ & 0.37 & 5.7 & 93 & 76 & 6.1 & 7 \\
\hline 13 & Lanai & Pacific & 9 & 3.1 & $\mathrm{~L}$ & 0.37 & 5.7 & 94 & 76 & 6.0 & 7 \\
\hline 14 & Tutuila & Pacific & 14 & 18 & $\mathrm{~L}$ & 0.25 & 3.0 & 297 & 60 & 6.0 & 1 \\
\hline 15 & Saipan & Pacific & 17 & 34 & $\mathrm{~L}$ & 0.27 & 5.0 & 384 & 100 & 5.8 & 2 \\
\hline 16 & Guam & Pacific & 14 & 210 & $\mathrm{~L}$ & 0.19 & 4.0 & 392 & 100 & 5.6 & 0 \\
\hline 17 & USVI & Caribbean & 6 & 42 & $\mathrm{R}$ & 0.41 & 15.4 & 45 & 42 & 5.4 & 7 \\
\hline 18 & Massachusetts & East Coast & 5 & 460 & $\mathrm{R}$ & 0.13 & 9.5 & 0 & 18 & 5.4 & -4 \\
\hline 19 & Yakutat & Alaska & 22 & 0.63 & $\mathrm{~L}$ & 0.33 & 9.4 & 108 & 98 & 5.4 & 4 \\
\hline 20 & Ebeye & Pacific & 12 & 1.8 & $\mathrm{~L}$ & 0.36 & 8.0 & 284 & 100 & 5.3 & 5 \\
\hline 21 & Rhode Island & East Coast & 5 & 190 & $\mathrm{R}$ & 0.12 & 10.4 & 0 & 30 & 5.1 & -3 \\
\hline 22 & Kodiak & Alaska & 9 & 16 & $\mathrm{~L}$ & 0.18 & 13.3 & 114 & 37 & 5.1 & -1 \\
\hline 23 & North Carolina & East Coast & 5 & 940 & $\mathrm{R}$ & 0.06 & 7.6 & 0 & 19 & 5.0 & -12 \\
\hline 24 & New York & East Coast & 5 & 460 & \begin{tabular}{l|l}
$R$ \\
\end{tabular} & 0.07 & 8.8 & 0 & 29 & 4.8 & -11 \\
\hline 25 & Tinian & Pacific & 9 & 5.0 & $\mathrm{~L}$ & 0.27 & 5.0 & 385 & 100 & 4.8 & 1 \\
\hline 26 & Rota & Pacific & 14 & 1.8 & $\mathrm{~L}$ & 0.27 & 7.0 & 389 & 100 & 4.7 & 3 \\
\hline 27 & Unalaska & Alaska & 8 & 5.2 & $\mathrm{~L}$ & 0.22 & 14.3 & 179 & 129 & 4.6 & 0 \\
\hline 28 & Saint Paul & Alaska & 10 & 0.43 & $\mathrm{~L}$ & 0.40 & 4.9 & 219 & 18 & 4.3 & 2 \\
\hline 29 & Maine & East Coast & 5 & 760 & \begin{tabular}{l|l} 
\\
$R$
\end{tabular} & 0.08 & 15.8 & 0 & 138 & 4.3 & -7 \\
\hline 30 & Naval Base Guam & Pacific & 14 & 27 & $\mathrm{~L}$ & 0.20 & 18.0 & 393 & 100 & 3.8 & 1 \\
\hline 31 & Sitka & Alaska & 13 & 13 & $\mathrm{~L}$ & 0.02 & 18.2 & 85 & 44 & 3.0 & -3 \\
\hline
\end{tabular}




\section{Discussion}

Ideally, the task of identifying and ranking viable wave energy sites would combine detailed cost data for a range of viable device designs with detailed site and market forecasts to quantify the economic value of potential projects. However, the wave energy industry is still emerging, and most of the existing cost data are for prototypes, the data for which have very little commercialscale relevance. A device design — or type - that is economical in one location may not be so in another. Some devices will be designed for deep water, others for shallow. Different devices will have differing shipping costs or may be capable of being assembled with minimal infrastructure and installed from relatively small ships. Some devices may be designed for capturing energy from large and energetic waves, while others capture energy from smaller waves that exist more frequently. Furthermore - as renewable portfolio standard deadlines approach, other incentives are introduced, and energy markets evolve in general - the economics of wave energy will change on regional and sub-regional scales.

In the context of these uncertainties, this work proposes a methodology for assessing viability in terms of scoring functions that capture many of the major factors that experts have identified to be important to wave energy project development. Higher scores indicate higher project viability. The scoring functions, weighting, and aggregation method are designed to emphasize siteidentification criteria that will be important to all wave technology types. Some factors - such as seasonal resource variability, extreme event likelihood, and distance to ports of varying capabilities - that many experts believe to be important are not included in this analysis because consistent data is unavailable or technology agnostic scoring could not be identified (Porter and Phillips 2016).

Table 4. Regional Summary Comparing Long-Term and Short-Term Analyses

\begin{tabular}{|c|c|c|}
\hline & Long-Term & Short-Term \\
\hline 1 & Oregon & Hawaii \\
\hline 2 & California & California \\
\hline 3 & Washington & Oregon \\
\hline 4 & Hawaii & Pacific Islands \\
\hline 5 & Puerto Rico & Washington \\
\hline 6 & $\begin{array}{l}\text { East coast } \\
\text { states }\end{array}$ & Puerto Rico \\
\hline 7 & Pacific Islands & East Coast states \\
\hline 8 & $\begin{array}{l}\text { Alaskan } \\
\text { communities }\end{array}$ & $\begin{array}{l}\text { Alaskan } \\
\text { communities }\end{array}$ \\
\hline
\end{tabular}


As markets evolve and new data become available, it will be valuable to refine this analysis. The detailed timeline of where wave energy development takes place is likely to depend on technology-cost details that are not yet fully understood and policy decisions that cannot be predicted. In the meantime, the results summarized in Table 4 are potentially valuable to investors, project developers, and government decision makers in guiding investment and policy decisions. Table 4 is derived from the long- and short-term scoring models (Tables 2 and 3 ). Intra-state locales are grouped together (i.e., the Hawaiian Islands, California); locales with resource below $10 \mathrm{~kW} / \mathrm{m}$ (East Coast) or loads smaller than $100 \mathrm{MW}$ (Pacific Islands) are grouped regionally. The rank in the summary table is taken as the highest rank from Tables 2 and 3 , of a locale within that region. States in the top half of both tables - Oregon, California, Hawaii-are likely to see economical wave development in coming decades. The remainder of this section describes regional opportunities and challenges in further detail.

\subsection{Pacific Northwest}

This analysis indicates that the Pacific Northwest is the highest-ranking region for long-term wave energy development in the United States. This is consistent with conventional wisdom in the wave energy industry. In particular, Oregon is identified as a premier location for long-term wave energy development. Having recognized this, state leaders and wave energy stakeholders began organizing to accelerate wave energy development in Oregon and the Northwest. The following initiatives began in 2007 and 2008:

- The Oregon Wave Energy Trust was established in 2007 as a public-private partnership dedicated to connecting stakeholders, conducting research, and engaging in public outreach and policy in support of wave energy development.

- The Northwest National Marine Renewable Energy Center (NNMREC) is a DOE-supported consortium of universities (Oregon State University, University of Washington, and University of Alaska Fairbanks). Started in 2008, NNMREC's mission is “to facilitate commercialization of marine energy technology, inform regulatory and policy decisions, and close key gaps in scientific understanding."

- Also in 2008, Oregon's governor directed that the Oregon Territorial Sea Plan should be updated to include considerations for siting ocean energy facilities (Geerlofs et al. 2011). This resulted in Part 5 of the Territorial Sea Plan (Use of the Territorial Sea for the Development of Renewable Energy Facilities or Other Related Structures, Equipment or Facilities, State of Oregon 2013).

Development of Part 5 was guided by the Oregon Statewide Planning Goal 19, which directs that new planning activities should protect marine ecosystems, fisheries, and other existing uses of the territorial sea. Driven by this guidance, Part 5 identified locations with minimal conflict and identified four zones as being Renewable Energy Facility Suitability Study Areas (REFSSAs) and two zones as being Renewable Energy Permit Areas (REPAs). REFSSAs are defined as locations requiring further study and that are "anticipated to have the lowest potential adverse effects." REPAs are locations where "there is an existing authorization for the development of renewable energy testing, research, or facilities" (e.g., Figure 8). 


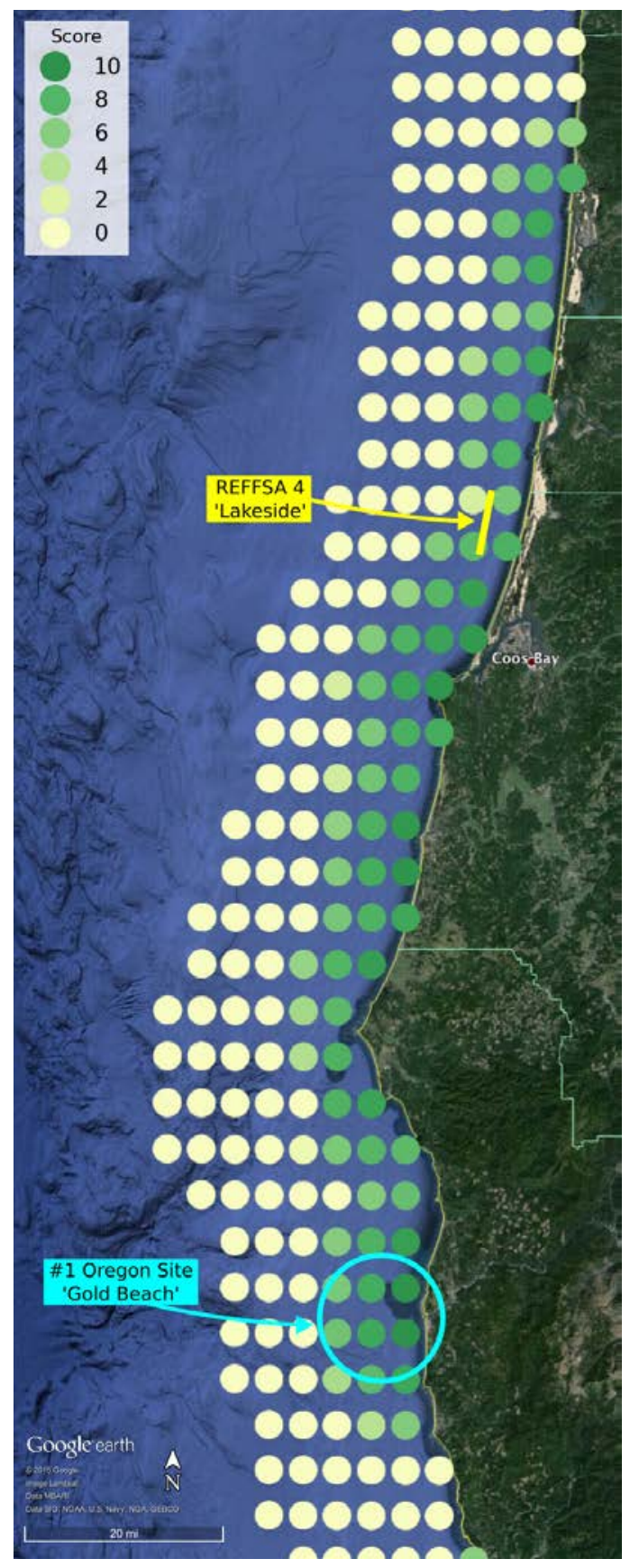

Figure 8. Scoring map along the Southern Oregon coast.

The map shows the highest ranking site under this analysis offshore of Gold Beach, Oregon (cyan). The approximate location of the lakeside REFFSA is in yellow. REFFSA 4 has a moderately high score in the long-term analysis $(\sim 8)$. 
REPA \#1 is NNMREC's Pacific Marine Energy Center North Energy Test Site. REPA \#2, known commonly as the Oregon Lakeside site, is a sub-area of REFSSA \#3 (Figure 8), and given these classifications these locations are among the top sites in the country for wave energy deployment. Additionally, REFFSA \#1 is the Oregon Camp Rilea site, where the army is working with wave energy developers to identify wave technologies that are suitable for the shallow waters there (Figure 9).

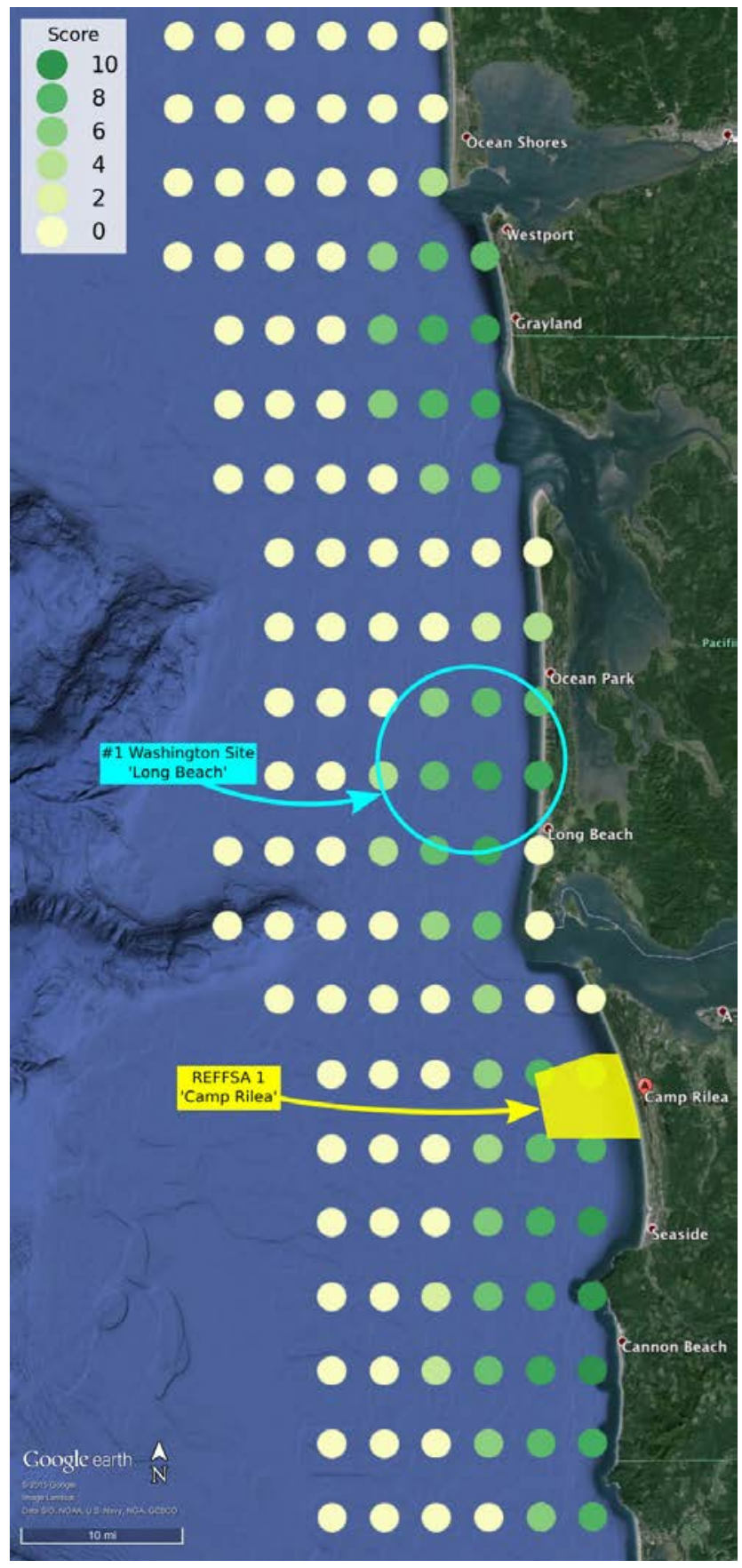

Figure 9. Map of scores at the Oregon - Washington border (the Columbia River).

The \#1 Washington wave energy site in this analysis is offshore of Long Beach, WA (cyan). Oregon REFFSA 1 is the Camp Rilea site (yellow), which also scores well. 
The shoreline just across the Columbia River in Washington offers the most likely sites for wave deployment in that state. Offshore of Long Beach, Ocean Park, and Grayland are particularly attractive because they possess the transmission infrastructure needed to bring wave energy to market.

A recent study for the Washington State Department of Natural Resources focused on identifying deployment sites along the Washington outer coast (Van Cleve et al. 2013)ii. Van Cleve et al.'s analysis confirms our finding that the most viable sites for wave energy development are along the state's southern coastline, where there is nearby transmission infrastructure. Another study simulated wave energy production in Oregon (Parkinson et al. 2015). That study predicted that wave energy production there would be highest in winter (consistent with the seasonality of the resource), and that integration costs of wave energy may be much lower than for wind energy because it is predictable.

In Northern California, the coastline offshore of Eureka, California, in Humboldt County, has long been considered an ideal location for wave technology development (Figure 10). The regional utility that serves Eureka, Pacific Gas and Electric, had pursued the WaveConnect project there starting in 2007 but abandoned it in 2010, citing installation and maintenance costs. As wave technology LCOE continues to decrease, this promising site is likely to become economical.

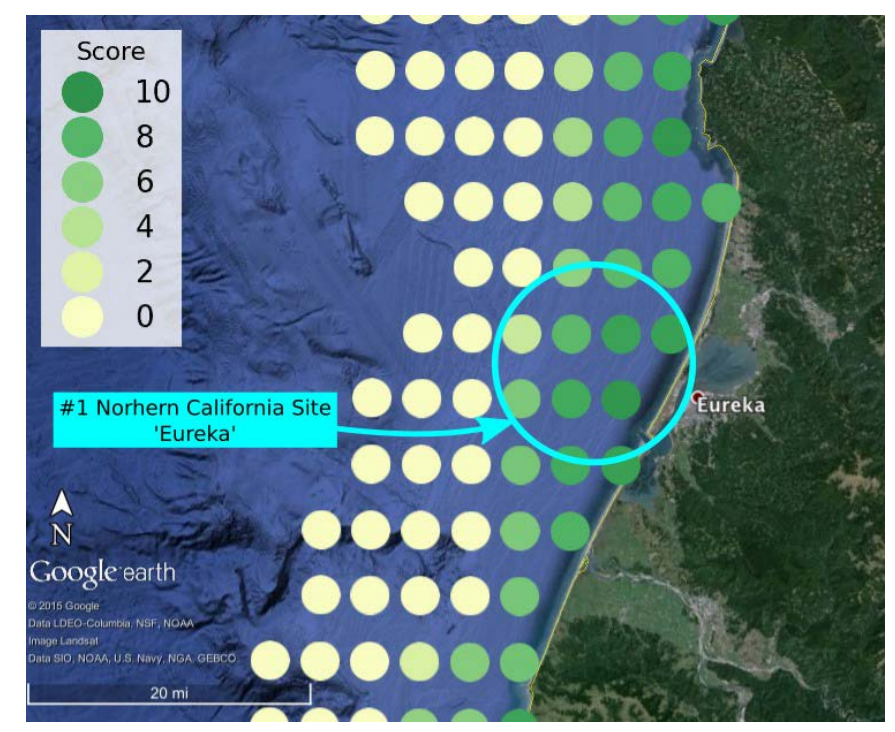

Figure 10. Map of scores in Northern California.

The highest-ranking site in this locale is offshore of Eureka (cyan).

Given the high rank of the Pacific Northwest in this analysis and work that has been done to identify specific sites within this region, there is a high likelihood that wave energy development will take place here in coming years.

\footnotetext{
ii The methods developed by Van Cleve et al. (2013) were highly influential in the development of this report.
} 


\subsection{Central and Southern California}

More recently, California wave energy stakeholders have been pursuing wave energy projects in Central and Southern California closer to high-capacity coastal transmission and heavy-lift infrastructure. In particular, California Polytechnic Institute is evaluating the feasibility of a gridconnected wave test center offshore of Vandenberg Air Force Base. This analysis finds that this location is the \#1 site for wave energy in Southern California (Figure 11). A more detailed analysis of this site is in progress under DOE funding to identify locations for U.S. test centers.

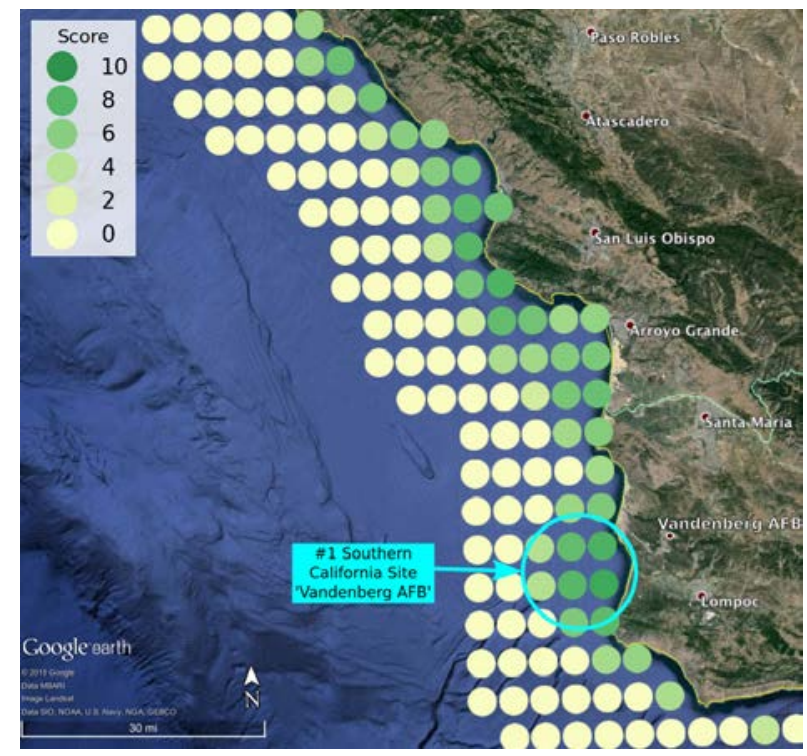

Figure 11. Southern California score map north of Point Conception.

The number one site for wave energy in this locale is offshore of Vandenberg Air Force Base (cyan).

There are also good sites (score >8) between Morro Bay and Avila Beach (i.e., west of San Luis Obispo). All of these sites are particularly attractive for their access to a large grid. Vandenberg, in particular, is attractive because the waters there are controlled by the Air Force.

\subsection{Hawaili and Pacific Island Territories}

Hawaii has a good wave energy resource and a significant demand for wave energy. Hawaii is particularly attractive as a wave energy development location in the short-term scenario because of the high energy prices on the islands. Even without bringing this factor into account, the north shore of the four largest Hawaiian Islands all rank well in this analysis. More detailed resource maps and analysis of development opportunities have been completed by local stakeholders and the University of Hawaii's Hawaii National Marine Renewable Energy Center (Stopa et al. 2013; Vega 2010).

All of the Hawaiian Islands could, theoretically, be powered by wave energy. A critical issue for the islands, however, is the fact that the water depth increases rapidly away from the islands' shores. Kauai, Maui, and the Big Island all have similarly high scores ( $>7.5)$ along their northern shoreline, where energetic waves from the North Pacific encounter the island coastlines. Oahu, in particular, scores highest among the islands primarily because it has the largest market (Figure 12). 


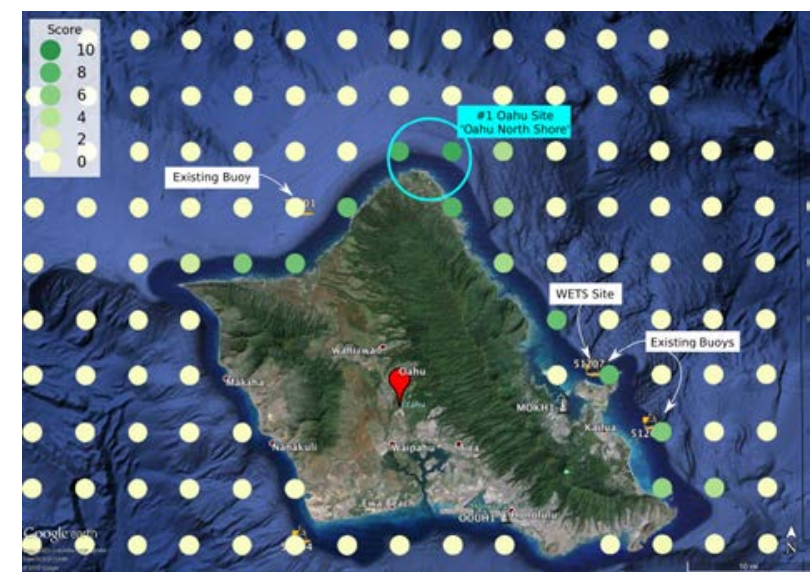

Figure 12. Oahu, Hawaii score map.

The highest ranking site for all of the Hawaiian Islands is at the northern tip of Oahu (cyan). Existing national Data Buoy Center buoys and the Wave Energy Test Site (WETS) are labeled in white.

The far Pacific is largely unexplored for wave energy development. There are currently no public reports that include the wave energy resource at these locations. The resource data used in this report were calculated from the U.S. Army Corps' Wave Information Systems database. Like the Hawaiian Islands, the far Pacific territories have high energy prices that may make short-term deployment of wave energy technology economically feasible before it is feasible in larger markets. More work is needed to identify the interest and conflicting uses that exist in these regions for wave energy. Site assessments and feasibility studies would be helpful in understanding the challenges and opportunities that exist in these locations.

\subsection{Alaska}

The southern coastline of Alaska holds $51 \%$ of the nation's wave energy resource, and the Bering Sea possesses another 8\% (Hagerman and Scott 2011). The challenge in Alaska is connecting that vast resource to a market that can utilize these "stranded renewables" (Johnson et al. 2012). The closest the primary power grid of the state comes to this resource is on the Kenai Peninsula south of Anchorage, where the WPD is less than $15 \mathrm{~kW} / \mathrm{m}$. The Aleutian Chain and southeast Alaska both have very large WPD, but demand for energy is relatively low there.

Though it is unlikely that wave energy will provide significant power to the Alaskan Railbelt in the foreseeable future, there are a few small communities along the Alaskan coastline that hold promise for wave energy development. Like the Hawaiian and Pacific Islands, these Alaskan communities often have high energy prices that lift their ranking in the short-term model.

First among these is Yakutat, which has a good WPD of $22 \mathrm{~kW} / \mathrm{m}$. There has already been some project development in Yakutat, and the community has shown interest in utilizing its wave energy resource to power their economy. Most notably, the local municipal-owned utility has performed upgrades of their transmission and primary generation infrastructure to facilitate integration with renewables. Yakutat is home to a fish processing plant that has struggled to compete with processors in other communities that have lower energy prices. Looking at a future in which wave energy begins to compete with traditional sources of electricity, it is intriguing to consider how Yakutat might grow and be transformed by low-cost wave energy. 
Kodiak, Alaska - located on an island of the same name - is a somewhat larger community that is exposed to the Gulf of Alaska. Its wave resource, however, is a paltry $9 \mathrm{~kW} / \mathrm{m}$ according to existing models. However, given the wide spacing between wave buoys for validating models in this region, it may be valuable to refine this estimate by measuring the wave resource near Kodiak.

Several other Alaskan communities may be viable wave energy deployment sites, especially when considering energy price (Table 2). However, these all have either a smaller resource or a smaller load, and they also generally have higher shipping costs. The Aleutian Chain, in particular, is a region where a somewhat larger market— by a few megawatts - might suddenly make a site very attractive to wave energy developers. This raises the concept of building a wave farm alongside infrastructure that would utilize the power. Potential uses of Alaska's stranded renewables include data centers, mining, smelting, fish processing, and alternative fuel production (Johnson et al. 2012). Data centers are a particularly intriguing concept considering that the Aleutian chain is at the nexus point between North America, Europe, and East Asia for the planned Arctic Fibre project. ${ }^{\text {iii }}$ This region has the added benefit of having significant passive cooling and ocean thermal energy conversion cooling opportunities. As the cost of alternative fuel production continues to decrease compared to traditional fuels, it may become feasible to export this green energy on the global market as well as utilize the energy locally for several key industries including mining, smelting, and fish processing.

iii http://arcticfibre.com 


\section{Conclusions}

There is broad consensus across the wave energy industry that it is crucial to continue testing and developing wave energy conversion technologies at test centers to refine and demonstrate their commercial readiness. As technologies pass this important stepping stone, it will be important to have sites identified and vetted for commercial deployment (Metocean Procedures Guide 2015). This work presents a methodology for identifying these sites and a preliminary ranking of U.S. sites. This provides a nationwide context for several prior works and works in progress that have looked at this issue at regional scales (Stopa et al. 2013; Van Cleve et al. 2013; Vega 2010).

The future of wave energy in the United States is likely to be centered in the Pacific Northwest. Oregon and Northern California, in particular, have vast wave energy resources and transmission/distribution infrastructure that suggest promising market opportunities as wave energy technology matures. Both of these states also have renewable portfolio standards that may help drive demand. Oregon is committed to $25 \%$ renewables by 2025 , and California has very recently committed to $50 \%$ by 2030 .

This work has not considered the regulatory and competing-use issues that are of critical importance in siting wave energy projects. Fishing, marine protected areas, endangered species, data-cable routes, surfing, and other similar considerations are all important factors that will need to be addressed as wave energy projects get started. Oregon has been leading the way in working with stakeholders - including fisherman and regulators - to identify sites along the state's coastline that are likely to see wave energy deployment. Given that work and Oregon's position at the top of this analysis, sites identified in Part 5 of the Oregon Territorial Sea Plan are among the most attractive sites in the United States. The Lakeside North and Camp Rilea sites, in particular, perform very well in this analysis and have existing designations for wave energy development in the Oregon Territorial Sea Plan. These sites are also likely to benefit from the research and development that will be generated at NNMREC's Pacific Marine Energy Center North Energy Test Site and the proposed South Energy Test Site.

Hawaii also stands out as a premier region where wave energy conversion is most likely to become economical, especially in the short-term. Hawaii recently became the first state in the nation to commit to a $100 \%$ renewable portfolio standard. The next step for MHK in Hawaii is working with local stakeholders to identify sites that have minimal conflicting use concerns. The islands are small, and the depth that is suitable for wave energy technology is a narrow strip near the north shore of the islands' coastlines. The state's recent commitment to $100 \%$ renewable energy by 2045 is an aggressive commitment that is likely to create demand for wave energy. As increasing numbers of devices are tested at the Hawaii Wave Energy Test Site, earnest debates about the compromises necessary to meet the state's goals are likely to identify wave energy as a critical resource.

Several Pacific Islands and rural Alaskan locations (e.g., Yakutat) are also attractive as shortterm markets, where high energy prices make wave technology deployment more attractive to project developers. The primary question at these locations is whether the demand for energy is high enough to justify project development costs. This represents a key opportunity for modest public investment to reduce the project development barrier: as these relatively small projects demonstrate commercial success, the industry will benefit greatly from the technical knowledge that is gained and the increasingly positive public image that comes with this success. 


\section{References}

Alaska Energy Authority. 2014. 2013 Power Cost Equalization Program Statistical Data by Community.

http://www.akenergyauthority.org/Content/Programs/PCE/Documents/FY13StatisticalRptComt. pdf

Baring-Gould, I., Hunsberger, R., Visser, C., Voss, P. 2011 Commonwealth of the Northern Mariana Islands Initial Technical Assessment Report. TP-7A40-50906. National Renewable Energy Laboratory (NREL), Golden, CO (United States).

http://www.nrel.gov/docs/fy11 osti/50906.pdf

Baring-Gould, I., Conrad, M., Haase, S., Hotchkiss, E., McNutt, P. 2011 Guam Initial Technical Assessment Report. TP-7A40-50580. National Renewable Energy Laboratory (NREL), Golden, CO (United States). http://www.nrel.gov/docs/fy11osti/50580.pdf

Batten, B., Polagye, B. 2013. NNMREC Accomplishments and Impacts 2009-2013. NNMREC Report \#5. Northwest National Marine Renewable Energy Center (NNMREC). Corvallis:

NNMREC. 55 pp. https://ir.library.oregonstate.edu/xmlui/handle/1957/39929

Bedard, M. 2008. Prioritized Research, Development, Deployment and Demonstration (RDD\&D) Needs: Marine and Other Hydrokinetic Renewable Energy. Electric Power Research Institute, Palo Alto, CA.

Busche, S., Conrad, M., Funk, K., Kandt, A., McNutt, P. 2011. American Samoa Initial Technical Assessment Report. TP-7A40-50905. National Renewable Energy Laboratory (NREL), Golden, CO (United States). http://www.nrel.gov/docs/fy11osti/50905.pdf

DeVisser, A., Cable, B., Vega, L. 2013. Wave Energy Test Site (WETS).

http://hinmrec.hnei.hawaii.edu/wp-content/uploads/2009/12/Wave-Energy-Test-Site-atKaneohe-Bay.pdf

Geerlofs, S., O’Neil, R.S., Hanna, L., Battey, H. 2011. "Siting wave energy on the Oregon coast: the Oregon territorial sea plan and siting analysis tools." Glob. Status Crit. Dev. Ocean Energy 127.

Hagerman, G., Scott, G. 2011. Mapping and Assessment of the United States Ocean Wave Energy Resource (No. 1024637). Electric Power Research Institute, Palo Alto, CA. http://www1.eere.energy.gov/water/pdfs/mappingandassessment.pdf

Hanson, J.L., Tracy, B.A., Tolman, H.L., Scott, R.D. 2009. "Pacific Hindcast Performance of Three Numerical Wave Models." J. Atmospheric Ocean. Technol. 26, 1614-1633. doi:10.1175/2009JTECHO650.1

Hawaiian State Energy Office. 2014. "Hawaii Energy Facts and Figures." http://energy.hawaii.gov/wp-content/uploads/2014/11/HSEO_FF_Nov2014.pdf 
International Electrotechnical Commission. 2011. Part 1: Terminology (Technical Specification No. 62600-1), Marine energy - Wave, tidal, and other water current converters.

International Electrotechnical Commission. 2015. Part 101: Wave energy resource assessment and characterization (Technical Specification No. 62600-101), Marine energy - Wave, tidal, and other water current converters.

Johnson, E., Meyer, J., Mager, M., Horel, A., Holdmann, G. 2012. Stranded Renewable Energy Resources of Alaska. Alaska Center for Energy and Power.

http://www.uaf.edu/files/acep/Standed-Renewables-Report-Final.pdf

Kilcher, L.; Thresher, R.; Tinnesand, H. 2016. Marine Hydrokinetic Energy Site Identification and Ranking Methodology Part II: Tidal Energy. NREL/TP-5000-66079. National Renewable Energy Laboratory (NREL), Golden, CO (United States).

http://www.nrel.gov/docs/fy17osti/66079.pdf

Mai, T., Sandor, D., Wiser, R., Schneider, T. 2012. Renewable Electricity Futures Study: Executive Summary. NREL/TP-6A20-52409-ES). National Renewable Energy Laboratory, Golden, CO (United States).

Marshalls Energy Company. http://mecrmi.net/ (accessed October 2016)

Metocean Procedures Guide for Offshore Renewables. 2015. Institute of Marine Engineering, Science and Technology.

Parkinson, S.C., Dragoon, K., Reikard, G., Garcia-Medina, G., Ozkan-Haller, H.T., Brekken, T.K. 2015. Integrating ocean wave energy at large scales: A study of the U.S. Pacific Northwest. Renew. Energy 76, 551-559.

Porter, A., Phillips. S. 2016. Determining the Infrastructure Needs to Support Offshore Floating Wind and Marine Hydrokinetic Facilities on the Pacific West Coast and Hawaii. Bureau of Ocean Energy Management.

Ruehl, K.M., Yu, Y.-H., Lawson, M., Michelen, C. 2014. Development and Demonstration of the WEC-Sim Wave Energy Converter Simulation Tool. SAND2014-3013. Sandia National Laboratories (SNL-NM), Albuquerque, NM (United States). http://energy.sandia.gov/wpcontent/gallery/uploads/SAND2014-3013.pdf

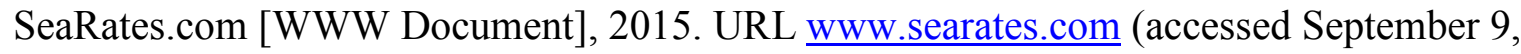
2015).

State of Oregon. 2013. "State of Oregon Territorial Sea Plan Part 5: Use of the Territorial Sea for the Development of Renewable Energy Facilities or Other Related Structures, Equipment, or Facilities." http://www.oregon.gov/LCD/docs/rulemaking/tspac/Part 5 FINAL_10082013.pdf

Stopa, Justin; Filipot, Jean-François; Li, Ning; Cheung, Kwok Fai; Chen, Yi-Leng; and Luis Vega. 2013. "Wave energy resources along the Hawaiian Island chain." Renew. Energy 55, 305321. Accessed March 1, 2016. doi:10.1016/j.renene.2012.12.030 
U.S. Energy Information Administration. Retail sales of electricity to ultimate customers by enduse sector, by state (No. 5.4), 2013. www.eia.gov/electricity/data/browser/

Van Cleve, F.B., Judd, C., Radil, A., Ahmann, J., Geerlofs, S.H. 2013. Geospatial Analysis of Technical and Economic Suitability for Renewable Ocean Energy Development on Washington's Outer Coast. PNNL-22554. Pacific Northwest National Laboratory, Richland, WA (United States). http://www.msp.wa.gov/wp-content/uploads/2013/07/PNNL_EnergySuitability_FinalReport.pdf

Vega, L. 2010. Wave Energy Resources for Representative Sites around the Hawaiian Islands. Hawaii National Marine Renewable Energy Center.

Wang, J.-J., Jing, Y.-Y., Zhang, C.-F., Zhao, J.-H. 2009. "Review on multi-criteria decision analysis aid in sustainable energy decision-making." Renewable and Sustainable Energy Reviews, 13, 2263-2278. 